\title{
Effect of Energy Intake on Performance and Carcass Composition of Broiler Chickens from Two Different Genetic Groups ${ }^{1}$
}

\begin{tabular}{l} 
- Author(s) \\
\hline Rosa $\mathrm{PS}^{2,3}$ \\
Faria Filho $\mathrm{DE}^{4}$ \\
Dahlke $\mathrm{F}^{5}$ \\
Vieira $\mathrm{BS}^{3}$ \\
Macari M ${ }^{3}$ \\
Furlan RL', \\
1 The authors thank PRODETA (Projeto de \\
Desenvolvimento de Tecnologia Agrícola) for \\
financial support. \\
2 Embrapa Suínos e Aves and Universidade \\
do Contestado, UnC. Concórdia, SC, Brazil. \\
3 Universidade Estadual Paulista \\
Faculdade de Ciências Agrárias e \\
Veterinárias. Departamento de M orfologia \\
e Fisiologia Animal. Jaboticabal, SP, Brazil. \\
4 Universidade Federal de Minas Gerais \\
Núcleo de Ciências Agrárias. Departamento \\
de Zootecnia. M ontes Claros, MG, Brazil. \\
5 Universidade Federal do Paraná \\
Departamento de Zootecnia. Curitiba, PR, \\
Brazil.
\end{tabular}

Mail Address

Renato Luis Furlan

Departamento de Morfologia e Fisiologia Animal.

Via de acesso Prof. Paulo D. Castelane, $s / n$. 14.884-900. Jaboticabal, SP, Brazil.

E-mail: rlfurlan@fcav.unesp.br

\section{Keywords}

Allometric growth, broiler chickens, carcass composition, energy intake, genetic strains.

\section{ABSTRACT}

In order to evaluate the effect of energy intake and broiler genotype on performance, carcass yield, and fat deposition, 600 one-day-old male chicks from two different genetic groups (AgRoss 308 - commercial line and PCLC - Embrapa non-improved line) were fed diets with different metabolizable energy level $(2950,3200$ and $3450 \mathrm{kcal} / \mathrm{kg}$ ). A completely randomized experimental design in a $2 \times 3$ factorial arrangement with four replications of 25 birds per treatment was applied. In order to ensure different energy intake among treatments within each strain, feed intake was daily adjusted by pair-feeding schemes. AgRoss 308 broilers had better performance and carcass yield, and presented lower abdominal fat deposition rate. In both genetic groups, the highest dietary energy level increased weight gain, heart relative weight, and fat deposition. However, it reduced the difference between AgRoss 308 and PCLC for feed conversion ratio and carcass protein deposition. These findings allow concluding that genetic improvement had a significant effect on broiler energy metabolism, and that the highest performance differences between genetic groups are found when low-energy intake is imposed.

\section{INTRODUCTION}

Energy intake is considered a fundamental factor in broiler production, not only because it affects growth rate and carcass characteristics (Boekholt et al., 1994; Leeson et al., 1996), but also because it is indirectly involved in metabolic diseases, such as ascites (Leeson et al., 1995). Therefore, finding the optimal point between economic and physiological optimal dietary energy level for broilers has been the goal of many researchers.

Leeson et al. (1996) showed that broiler feed intake increases linearly with decreasing dietary energy level. Albuquerque et al. (2003) also described reduction in feed intake due to higher dietary energy density. In addition, Leeson et al. (1996) found that broilers fed free-choice on diets with either 2700 or $3300 \mathrm{kcal}$ metabolizable energy/kg presented the same growth rate and constant energy consumption. These findings together suggest that broilers do control their feed intake in order to supply energy requirements, and one of its most important consequences is the possibility of formulating feeds based on predicted intake according to dietary energy level.

However, comparing broilers during finishing phase in two ad libitum programs (3,200 and 3,600 kcal/kg of diet), Araújo (1998) did not find any differences in feed intake between the groups, and observed better daily gain in the group fed the high-energy diet. The fact that higher energy consumption promotes better weight gain is well established (Boekholt et al., 1994; Lesson et al., 1996); however, why dietary energy 
Rosa PS, Faria Filho DE, Dahlke F, Vieira BS, Macari M, Furlan RL level does not affect broiler feed intake in some cases remains unanswered. In fact, the nutritional factors involved in broiler feed intake control mechanisms are not completely understood, and seemingly other macronutrients than energy influence feed behavior. In mammals it is well established that protein is the first nutrient in the hierarchy of oxidation, followed by carbohydrates and fat, which corresponds to their ability to induce satiety (Stubbs et al., 1997). In avian species, this chain is not well described, and differences may influence feeding behavior.

One possible negative consequence of broiler genetic improvement is the loss of sensitivity to regulate feed intake according to dietary energy level. In fact, Richards (2003) reported that broilers selected both for rapid weight gain and muscular mass deposition do not properly regulate voluntary feed intake according to energy level, as in an ad libitum program they showed compulsive appetite and excessive fat accumulation. Taking this statement to an experimental vision it is clear that it is difficult to assess different energy consumption of broilers if their feed intake was not restricted.

In the few last years, the close link between dietary energy to protein ratio and broiler carcass composition was investigated by several researches (Summers et al., 1992; Leeson et al., 1996; Swennen et al., 2004). In general, energy retention as fat increases as the ratio rises. This statement could explain many of the
Effect of Energy Intake on Performance and Carcass Composition of Broiler Chickens from Two Different Genetic Groups differences in carcass chemical composition found in literature; nevertheless, the differences in broiler responsiveness to dietary energy level through selection for increased growth rate were little explored in literature. Thus, the objective of the present study was to evaluate the effect of energy intake of genetically selected or non-selected broiler chickens on performance, carcass yield and fat deposition.

\section{MATERIAL AND METHODS}

Eggs from a broiler line selected for rapid growth rate (AgRoss 308) and from a genetically stabilized population (PCLC - an Embrapa experimental meat line maintained by random mating since 1984) were incubated according to commercial practices in a Petersime machine with capacity of 5,000 eggs. The initial chick weight was $47.5 \pm 0.01$ and $45.8 \pm 0.01 \mathrm{~g}$ for PCLC and AgRoss 308, respectively.

A total of 600 chicks were randomly placed in floor pens, and submitted to diets with different metabolizable energy levels $(2950,3200$, and 3450 $\mathrm{kcal} / \mathrm{kg}$ ). A completely randomized experimental design in a $2 \times 3$ factorial arrangement (genetic group and dietary metabolizable energy level), totalizing six treatments with four replicates of 25 birds each, was applied. Diets (Table 1) were formulated according to the NRC (1994) recommendations. In order to ensure different energy consumption among treatments within

\begin{tabular}{|c|c|c|c|c|c|c|}
\hline \multicolumn{2}{|l|}{ Ingredients (\%) } & \multicolumn{2}{|c|}{ Starter diets } & \multicolumn{3}{|c|}{ Grower diets } \\
\hline Corn & 57.43 & 51.54 & 45.61 & 67.10 & 61.21 & 55.30 \\
\hline Soybean meal $(45 \%)$ & 36.49 & 37.60 & 38.70 & 29.20 & 30.30 & 31.40 \\
\hline Soybean oil & 2.27 & 7.07 & 11.89 & 0.46 & 5.27 & 10.08 \\
\hline Dicalcium phosphate & 1.81 & 1.82 & 1.84 & 1.30 & 1.32 & 1.33 \\
\hline Limestone & 1.10 & 1.09 & 1.07 & 1.22 & 1.21 & 1.19 \\
\hline Sodium chloride & 0.41 & 0.41 & 0.41 & 0.29 & 0.29 & 0.29 \\
\hline Choline chloride $60 \%$ & 0.10 & 0.10 & 0.10 & 0.10 & 0.10 & 0.10 \\
\hline DL-M ethionine $98 \%$ & 0.16 & 0.16 & 0.17 & 0.07 & 0.07 & 0.08 \\
\hline L-Lysine $\mathrm{HCl}$ 98\% & 0.02 & - & - & 0.02 & - & - \\
\hline L-Threonine $98 \%$ & - & - & - & 0.03 & 0.02 & 0.02 \\
\hline Coxistac $12 \%{ }^{\circledR}$ & 0.05 & 0.05 & 0.05 & 0.05 & 0.05 & 0.05 \\
\hline Zinc bacitracine $15 \%$ & 0.04 & 0.04 & 0.04 & 0.04 & 0.04 & 0.04 \\
\hline Antioxidant (Banox) & 0.02 & 0.02 & 0.02 & 0.02 & 0.02 & 0.02 \\
\hline Suplement ${ }^{1}$ (1 kg/ton) & 0.10 & 0.10 & 0.10 & 0.10 & 0.10 & 0.10 \\
\hline Total & 100.0 & 100.0 & 100.0 & 100.0 & 100.0 & 100.0 \\
\hline Energy and Nutrients & \multicolumn{6}{|c|}{ Calculated Composition } \\
\hline Metabolizable energy (kcal/kg) & 2,950 & 3,200 & 3,450 & 2,950 & 3,200 & 3,450 \\
\hline Crude protein $(\%)$ & 21.50 & 21.50 & 21.50 & 19.00 & 19.00 & 19.00 \\
\hline Calcium $(\%)$ & 1.00 & 1.00 & 1.00 & 0.90 & 0.90 & 0.90 \\
\hline Available phosphorus (\%) & 0.45 & 0.45 & 0.45 & 0.35 & 0.35 & 0.35 \\
\hline Sodium $(\%)$ & 0.20 & 0.20 & 0.20 & 0.15 & 0.15 & 0.15 \\
\hline Energy/Protein ratio (kcal/g CP) & 137.2 & 148.8 & 160.5 & 155.3 & 168.4 & 181.6 \\
\hline
\end{tabular}

1 - Vitamin/M ineral supplement - Levels per kg diet: vitamin A, 7,000 IU; vitamin D, 3,000 IU; vitamin E, 25 mg; vitamin K, 1 mg; thiamin, 1.8 mg; riboflavin, $9.6 \mathrm{mg}$; pyridoxine, $3.5 \mathrm{mg}$; vitamin B , $10 \mathrm{mcg}$; biotin, 1,6 mg; pantothẻnic acid, $9.5 \mathrm{mg} ;$ nicotinic acid, $35 \mathrm{mg} ;$ antioxidant (Banox), 0,1 mg; Copper, 10 mg; lodine, 1.3 mg; manganese, 76 mg; selenium, 0.27 mg; zinc, 91 mg; iron, 80 mg. 
Rosa PS, Faria Filho DE, Dahlke F, Vieira BS, Macari M, Furlan RL
Effect of Energy Intake on Performance and Carcass Composition of Broiler Chickens from Two Different Genetic Groups each genetic group, feed intake was daily adjusted by pair-feeding schemes. Thus, the amount of feed provided for all replications within each genetic group was equivalent to the mean feed intake of the treatment with lower consumption obtained in the day before. Water was supplied ad libitum throughout the experiment.

The trial was carried out in climatic chambers, where the chicks were reared during 42 days. Light regime was continuous, with 24-hour artificial light, and temperature was kept at thermoneutrality: $29.5 \pm 1.2{ }^{\circ} \mathrm{C}$ from 1 to 7 days of age; $26.7 \pm 0.6$ ㅇ $\mathrm{C}$ from 8 to 14 days of age; $26.0 \pm 1.2^{\circ} \mathrm{C}$ from 15 to 21 days of age; and $25.2 \pm 1.3^{\circ} \mathrm{C}$ from 22 to 42 days of age.

Broilers and feeds were weighted at day 42 to calculate performance characteristics. In order to assess carcass characteristics, two broilers in each replicate (mean group weight $\pm 100 \mathrm{~g}$ ) were water- and feed-deprived for 5 hours, and were subsequently bled. Broilers were then scalded, defeathered, and eviscerated. Carcasses (without head, neck, feet and lungs) were cut into pieces to obtain breast, thighs+drumsticks, and wings weights (with skin and bones). After that, one carcass was frozen at $-20{ }^{\circ} \mathrm{C}$ for further chemical evaluation. Liver and heart were weighted, as well as abdominal fat, which was considered as all of adipose tissues surrounding the cloaca and adhering to the gizzard. Carcass, breast, thighs+drumsticks, wings, heart, liver, and abdominal fat yield values were calculated relative to broiler live weight at slaughter.

In order to obtain total dry matter, carcasses were ground, homogenized, pre-dried $\left(60^{\circ} \mathrm{C} / 72 \mathrm{~h}\right)$, and completely dried $\left(100^{\circ} \mathrm{C} / 24 \mathrm{~h}\right)$. Seubsequently, crude protein (micro Kjeldahl) and ether extract (Soxhlet) analyses were performed following the procedures described by AOAC (1990).

Data were first tested for normality (Shapiro-Wilk test), and homogeneity of variances (Levene's test). As these assumptions were not violated, data were submitted to analyses of variance by the General Linear Model procedure of SAS ${ }^{\circledR}$. When statistical difference was detected $(p<0.05)$, means were compared by the test of Tukey $(5 \%)$. Data are expressed as mean \pm standard error of the mean (SEM). Abdominal fat deposition rate was evaluated by the allometric coefficient $\beta$ (beta) value in the allometric growth equation: $\log$ y (abdominal fat) $=\alpha+\beta$ [log $\mathrm{x}$ (body weight)], as proposed by Huxley \& Teissier (1936). In order to assess allometric nature, the hypothesis was tested $\beta=1$ vs $\beta>1$ by Student's t test. Thus, $\beta=1$ indicates similar rates of fat deposition and body growth, and $\beta>1$ shows higher fat deposition as compared to body growth. All statistics were performed using the Statistical Analysis System - SAS ${ }^{\circledR}$ (Littell et al., 2002).

\section{RESULTS AND DISCUSSION}

\section{Performance}

Analysis of variance was not applied for feed intake, since it was kept constant among treatments within the same strain. M ean feed intake for PCLC and AgRoss 308 broilers was $3,235 \pm 32.6$ and $4,312 \pm 41.6 \mathrm{~g}$, respectively, which represent a difference of $25 \%$ between genetic groups.

No significant interaction was observed between genetic group and dietary metabolizable energy level for weight gain (Table 2); therefore, only the main treatment effects will be discussed. AgRoss 308 group weight gain was $46 \%$ higher than PCLC. Analyzing performance differences between typical 1957 and 1991 broilers, Havenstein et al. (1994a) reported a weight gain improvement of more than $300 \%$ during this period. The authors also found the diet based on 1991 recommendations improved non-selected line weight gain in $26 \%$ at 43 days. As PCLC line represents a more modern broiler than 1957 one, these significant differences were expected. A comparison between diets reveals progressive rise in weight gain according to elevation in energy consumption. Leeson et al. (1996) also observed improvement in weight gain according to rise in energy consumption; however, as broilers are capable of controling feed intake according to energy requirements, the same results were not described when diets with different energy levels were applied in an ad libitum feed program.

A significant interaction between genetic group and dietary metabolizable energy level for feed conversion (Table 2) was observed. The comparison between genetic groups within each dietary energy level reveals that AgRoss 308 broilers had better feed conversion ratio than PCLC broilers in all dietary energy levels. These results are consistent with those described by Havenstein et al. (1994a), who found a $23 \%$ improvement in feed conversion ratio from 1957 to 1991 when male broilers were fed a diet formulated according 1991 recommendations. In addition, both genetic groups showed improvement in feed conversion ratio as energy consumption increased. This result can be explained by the fact that weight gain increased according to the elevation of energy consumption, while feed intake was kept equal. 


\begin{tabular}{|c|c|c|c|c|}
\hline \multirow[t]{2}{*}{ Variables } & \multirow{2}{*}{$\begin{array}{c}\text { Metabolizable } \\
\text { energy (kcal/kg) }\end{array}$} & \multicolumn{2}{|c|}{ Genetic group } & \multirow[t]{2}{*}{ Mean } \\
\hline & & PCLC & AgRoss 308 & \\
\hline & 2,950 & $1599 \pm 14$ & $2387 \pm 21$ & $1993 \pm 150^{c}$ \\
\hline \multirow[t]{4}{*}{ Weight gain } & 3,200 & $1714 \pm 22$ & $2499 \pm 19$ & $2106 \pm 149^{b}$ \\
\hline & 3,450 & $1781 \pm 19$ & $2550 \pm 18$ & $2165 \pm 146^{a}$ \\
\hline & Mean & $1698 \pm 23^{B}$ & $2478 \pm 22^{A}$ & \\
\hline & 2,950 & $2.02 \pm 0.01^{\mathrm{aA}}$ & $1.81 \pm 0.01^{\mathrm{aB}}$ & $1.92 \pm 0.04$ \\
\hline \multirow[t]{3}{*}{ Feed conversion ratio ${ }^{1}$} & 3,200 & $1.89 \pm 0.01^{\mathrm{bA}}$ & $1.73 \pm 0.01^{\mathrm{bB}}$ & $1.81 \pm 0.03$ \\
\hline & 3,450 & $1.82 \pm 0.01^{\mathrm{CA}}$ & $1.69 \pm 0.02^{\mathrm{bB}}$ & $1.75 \pm 0.03$ \\
\hline & Mean & $1.91 \pm 0.03$ & $1.74 \pm 0.02$ & \\
\hline
\end{tabular}

1 - Significant interaction between factors. Different capital letters indicate significant difference among means in the same row (Tukey's test; $p<0.05$ ). Different small letters indicate significant difference among means in the same column (Tukey's test; $p<0.05$ ).

The difference between AgRoss 308 and PCLC for feed conversion ratio decreased as the energy consumption increased, changing from $12 \%$ to $8 \%$ for the lowest and the highest dietary energy levels, respectively. This finding is important, and shows that PCLC broilers have better capacity to increase their weight gain in response an increase in energy intake, since the feed intake was maintained the same inside each genetic group.

\section{Carcass, parts, viscera, and abdominal fat yields}

There was no significant interaction between genetic group and dietary metabolizable energy level for carcass, parts, viscera, and abdominal fat yields of broilers at 42 days of age (Table 3 ). As to genetic group, AgRoss 308 broilers show ed higher carcass, breast, and thighs+drumsticks yields than PCLC broilers. Commercial broilers showed almost $5 \%$ better carcass yield, which difference is very similar to that described by Havenstein et al. (1994b) between 1957 and 1991 broilers at 43 days of age. This was also observed for breast yield. In addition, Havenstein et al. (1994b) observed that the difference between genetic groups in breast yield increased with time, an indication that selected broilers do deposit more muscular mass in the breast than the non-selected ones.

AgRoss 308 broilers had lower heart, liver, and wings yields than PCLC. Similar results were found by Havenstein et al. (1994b) for heart and wings. The lower heart and liver relative weight of the AgRoss 308 group may indicate that genetically selected broilers are more sensitive to metabolic diseases. In fact, higher mortality levels associated with metabolic diseases have been observed in modern broilers (Gonzales \& M acari, 2000).

Commercial broilers deposited less abdominal fat than PCLC broilers. Considering the precocity of the improved line, an opposite behavior was expected. In fact, Havenstein et al. (1994b) found that genetically improved broilers deposited abdominal fat at a higher rate than the non-selected until 85 days of age. Nevertheless, after this time, total carcass fat was the same between genetic groups. Such discrepant results may have occurred due genetic differences between PCLC line and the 1957 line used by the authors.

Dietary energy level did not affect carcass, breast, and wings yields (Table 3 ), even though energy consumption was directly related to weight gain (Table 2). Leeson et al. (1996), Oliveira Neto et al. (1999), Albuquerque et al. (2003), and Sakomura et al. (2004) also found that dietary metabolizable energy level did not affect carcass yield in broilers at slaughte age. However, Araújo (1998) found that broilers fed 3600 $\mathrm{kcal} / \mathrm{kg}$ increased carcass and breast yields as compared to those fed $3200 \mathrm{kcal} / \mathrm{kg}$. Broilers fed the $2950-\mathrm{kcal} / \mathrm{kg}$ diet increased thighs+drumsticks yield, and reduced relative heart weight. Broilers fed 3200 $\mathrm{kcal} / \mathrm{kg}$ presented the lowest liver percentage.

The lowest energy diet $(2950 \mathrm{kcal} / \mathrm{kg})$ decreased abdominal fat as compared to the other diets. Leeson et al. (1996) found that an increase in dietary energy level was followed by higher abdominal fat deposition. However, Oliveira Neto et al. (1999) and Albuquerque et al. (2003) did not find significant effect of dietary energy level on abdominal fat deposition in broilers. In fact, abdominal fat depot areas are considered as main location of excessive energy deposition (Summers et al., 1992). Therefore, we could conclude that the two highest energy consumption levels in this trial were not very different in terms of total energy available to the broilers. However, this kind of measurement could be a poor parameter when studying carcass fat deposition (Summers et al., 1992), and a more precise interpretation of energy metabolism would be assessed by measuring total fat deposition in the carcass. Excessive abdominal fat deposition delays processing procedures, and may cause problems during carcass evisceration. 


\begin{tabular}{|c|c|c|c|c|c|}
\hline \multirow{2}{*}{$\begin{array}{l}\text { Yield } \\
\text { (\% of body weight) }\end{array}$} & \multicolumn{2}{|c|}{ Genetic group } & \multicolumn{3}{|c|}{ Metabolizable energy (kcal/kg) } \\
\hline & PCLC & AgRoss 308 & 2,950 & 3,200 & 3,450 \\
\hline Carcass & $62.4 \pm 1.5^{B}$ & $67.1 \pm 1.2^{\mathrm{A}}$ & $65.3 \pm 2.1$ & $64.6 \pm 3.0$ & $64.2 \pm 3.3$ \\
\hline Breast & $17.3 \pm 0.8^{B}$ & $22.8 \pm 0.9^{A}$ & $20.3 \pm 2.6$ & $20.3 \pm 3.4$ & $19.5 \pm 3.0$ \\
\hline Thighs+drumsticks & $22.2 \pm 0.6^{B}$ & $22.9 \pm 0.7^{A}$ & $23.0 \pm 0.9 a$ & $22.2 \pm 0.6 b$ & $22.4 \pm 0.4 b$ \\
\hline Wings & $8.7 \pm 0.2^{A}$ & $7.9 \pm 0.2^{B}$ & $8.4 \pm 0.6$ & $8.2 \pm 0.5$ & $8.2 \pm 0.5$ \\
\hline Heart & $0.56 \pm 0.03^{A}$ & $0.45 \pm 0.03^{B}$ & $0.48 \pm 0.05^{b}$ & $0.50 \pm 0.06^{\mathrm{ab}}$ & $0.53 \pm 0.07^{a}$ \\
\hline Liver & $1.9 \pm 0.1^{A}$ & $1.7 \pm 0.1^{B}$ & $1.8 \pm 0.1^{\mathrm{a}}$ & $1.7 \pm 0.14^{b}$ & $1.8 \pm 0.15^{\mathrm{a}}$ \\
\hline Abdominal fat & $2.6 \pm 0.5^{A}$ & $2.1 \pm 0.5^{B}$ & $1.9 \pm 0.4^{b}$ & $2.6 \pm 0.6^{a}$ & $2.6 \pm 0.3^{a}$ \\
\hline
\end{tabular}

Different capital letters indicate significant difference among means in the same row (Tukey's test; $p<0.05$ ). Different small letters indicate significant difference among means in the same column (Tukey's test; $p<0.05$ ).

\section{Carcass chemical composition}

A significant interaction was observed between genetic group and dietary metabolizable energy level for crude protein and ether extract carcass percentages (Table 4). A comparison of dietary energy levels within each genetic group indicates differences in their protein and energy metabolism. In AgRoss 308 strain, ether extract carcass deposition was directly related to energy consumption, i.e., the highest energy consumption promotes the fattest carcass. Opposite behavior was observed for crude protein carcass deposition. When feed intake was maintained the same within each genetic group, dietary energy: protein ratio linearly dropped as energy consumption decreased. Thus, the lower the dietary energy: protein ratio, the leaner the carcass. This find is consistent with Summers et al. (1992) and Boekholt et al. (1994), who also found a reduction in fat deposition due to a decrease in dietary energy: protein ratio.

When the effect of genetic group within each dietary energy level was analyzed, it was observed that AgRoss 308 genetic superiority for carcass composition was lost as energy consumption increased. Thus, total protein deposition was lower and equal for both genetic groups at the highest energy: protein ratio. Similarly, AgRoss 308 deposited less fat than PCLC when fed with the lowest dietary energy level. These findings may corroborate the tendency of reducing dietary energy level for modern broilers; however, although low-energy diets promote low fat and high protein deposition in carcasses - which is desirable -, it is important to emphasize that a decrease in energy consumption leads to lower productive performance.

\section{Allometric coefficient " $\beta$ " for abdominal fat}

The interaction between genetic group and dietary metabolizable energy level was not significant for abdominal fat (Table 3). Thus, allometric coefficient $\beta$ estimates for abdominal fat shown on Table 5 consider only the mean effects. All estimates showed $\beta>1$, indicating higher abdominal fat deposition rate as compared to growth rate, independent of genetic group or dietary energy level. However, $\beta$ coefficient was lower in AgRoss 308 broilers than in PCLC ones, showing that the commercial line deposits less abdominal fat than non-improved line. In addition, allometric coefficient $\beta$ for abdominal fat increased as dietary metabolizable energy level rose, indicating higher rate of abdominal fat deposition.

\section{CONCLUSIONS}

1. Commercial broilers do respond differently than non-selected ones to dietary energy consumption level, and the highest differences

\begin{tabular}{|c|c|c|c|c|}
\hline \multirow[t]{3}{*}{ Variables } & \multirow{2}{*}{$\begin{array}{c}\text { Metabolizable } \\
\text { energy (kcal/kg) }\end{array}$} & \multicolumn{2}{|c|}{ Genetic group } & \multirow[t]{2}{*}{ Mean } \\
\hline & & PCLC & AgRoss 308 & \\
\hline & 2,950 & $50.7 \pm 0.9^{a b B}$ & $59.4 \pm 0.4^{\mathrm{aA}}$ & $55.0 \pm 4.7$ \\
\hline \multirow[t]{4}{*}{ Crude protein $^{1}$} & 3,200 & $51.4 \pm 1.3^{\mathrm{aB}}$ & $54.0 \pm 0.5^{\mathrm{bA}}$ & $52.7 \pm 1.7$ \\
\hline & 3,450 & $49.4 \pm 0.5^{b A}$ & $50.9 \pm 0.3^{\mathrm{CA}}$ & $50.1 \pm 0.9$ \\
\hline & Mean & $50.5 \pm 1.2$ & $54.8 \pm 3.7$ & \\
\hline & 2,950 & $41.2 \pm 0.9^{a b A}$ & $31.7 \pm 0.3^{\mathrm{CB}}$ & $36.4 \pm 5.2$ \\
\hline \multirow[t]{3}{*}{ Ether extract ${ }^{1}$} & 3,200 & $39.7 \pm 1.2^{\mathrm{bA}}$ & $38.5 \pm 0.5^{\mathrm{bA}}$ & $39.0 \pm 1.0$ \\
\hline & 3,450 & $42.5 \pm 0.8^{\mathrm{aA}}$ & $41.7 \pm 0.3^{\mathrm{aA}}$ & $42.1 \pm 0.7$ \\
\hline & Mean & $41.2 \pm 1.5$ & $37.3 \pm 4.4$ & \\
\hline
\end{tabular}

1 - Significant interaction between factors. Different capital letters indicate significant difference among means in the same row (Tukey's test; $\mathrm{p}<0.05)$. Different small letters indicate significant difference among means in the same column (Tukey's test; $p<0.05$ ). 
Table 5 - Allometric coefficient $\beta$ for abdominal fat of broilers at 42 days of age.

\begin{tabular}{|c|c|c|c|c|c|}
\hline Genetic group & Metabolizable energy ( kcal $/ \mathbf{k g}$ ) & a* & $b^{* *}$ & $\mathbf{P}$ & $\mathbf{R}^{2}$ \\
\hline PCLC & - & -8.7129 & $1.68772^{\mathrm{a}}$ & $<0.0001$ & 0.955 \\
\hline AgRoss 308 & - & -6.6157 & $1.35320^{\mathrm{b}}$ & $<0.0001$ & 0.952 \\
\hline- & 2,950 & -5.6702 & $1.22977^{\mathrm{b}}$ & 0.0059 & 0.893 \\
\hline- & 3,200 & -6.9992 & $1.42713^{\mathrm{ab}}$ & $<0.0001$ & 0.910 \\
\hline- & 3,450 & -7.3691 & $1.47751^{\mathrm{a}}$ & $<0.0001$ & 0.920 \\
\hline
\end{tabular}

Fitted equation: $\log y$ (abdominal fat) $=\alpha+\beta[\log x$ (body weight)]. *All alpha values are different from 0 (Student's t test, $p<0.05) . * *$ All beta values are higher than 1 (Student's $t$ test, $p<0.05$ ); different letters indicate difference among each variation source (Student's t test, $p<0.05$ ).

between genetic groups are found when lowenergy consumption is imposed.

2. Genetic improvement allowed commercial broilers to reduce allometric grow th of abdominal fat despite energy consumption level. Nevertheless, total carcass fat deposition was reduced only in a low-energy consumption schedule.

\section{REFERENCES}

Albuquerque R, Faria DE, Junqueira OM, Salvador D, Faria Filho DE, Rizzo MF. Effects of energy levels in finisher diets and slaughter age of on performance and carcass yield in broiler chickens. Brazilian Journal of Poultry Science 2003; 5(2):99-104.

AOAC - Association of Official A nalytical Chemists. Official M ethods of Analysis of the Association of Official Analytical Chemists. $15^{\text {th }}$ ed. Washington (DC); 1990. p.1094.

Araújo LF. Avaliação do desempenho e rendimento de carcaça de frangos de corte submetidos a dietas com altos níveis de energia, metionina+cistina e lisina na fase final de criação [dissertação]. Jaboticabal (SP): UNESP; 1998.

Boekholt HA, Van Der Grinter PH, Schreurs VVAM , Los MJN, Lefering $\mathrm{CP}$. Effect of dietary energy restriction on retention of protein, fat and energy in broiler chickens. British Poultry Science 1994; 35(4): 603-614.

Gonzales E, Macari M. Enfermidades metabólicas em frangos de corte. In: Berchieri Júnior A, Macari M, editor. Doenças das aves. Jaboticabal: FUNEP-UNESP; 2000. p. 449-464.

Havenstein GB, Ferket PR, Scheideler SE, Larson BT. Growth, livability, and feed conversion of 1957 vs 1991 broilers when fed "Typical" 1957 and 1991 broiler diets. Poultry Science 1994a; 73(12):17851794.

Havenstein GB, Ferket PR, Scheideler SE, Rives DV. Carcass composition and yield of 1991 vs 1957 broilers when fed "Typical" 1957 and 1991 broiler diets. Poultry Science 1994b; 73(12):17951804.

Huxley JS, Teissier G. Terminology of relative growth. Nature 1936; 137:780-781.
Leeson S, Caston L, Summers JD. Broiler response to diet energy. Poultry Science 1996; 75(4):529-535.

Leeson S, Diaz G, Summers JD. Ascites. In: Leeson S, Diaz G, Summers JD. Poultry metabolic disorders and mycotoxins. Guelph: University Books; 1995. p. 43-44.

Littell RC, Stroup WW, Freund RJ. SAS for Linear Models. $4^{\text {th }}$ ed. Cary (NC): SAS Institute; 2002.

NRC - National Research Council. Nutrient Requirements of Poultry. Washington: National Academy Press; 1994.

Oliveira Neto AR, Oliveira RFM, Donzele JL, Albino LFT, Valerio SR, Carmo HM. Níveis de energia metabolizável para frangos de corte no período de 22 a 42 dias de idade mantidos em condições de estresse de calor. Revista Brasileira de Zootecnia 1999; 28:10541062.

Richards M P. Genetic regulation of feed intake and energy balance in poultry. Poultry Science 2003; 82(6):907-916.

Sakomura NK, Longo FA, Rabello CBV, Watanabe K, Pelicia K, Freitas ER. Efeito do nível de energia metabolizável da dieta no desempenho e metabolismo energético de frangos de corte. Revista Brasileira de Zootecnia 2004; 33(6):1758-1767.

Stubbs RJ, Prentice AM, James WPT. Carbohydrates and energy balance. Annals of the New York Academy Sciences 1997; 819 (1):44-69.

Summers JD, Spratt D, Atkinson JL. Broiler weight gain and carcass composition when fed diets varying in amino acid balance, dietary energy, and protein level. Poultry Science 1992; 71(2):263-273.

Swennen Q, Janssens GPJ, Decuypere E, Buyse J. Effects of substitution between fat and protein on feed intake and its regulatory mechanisms in broiler chickens: energy and protein metabolism and diet-induced thermogenesis. Poultry Science 2004; 83(12):1997-2004. 